\title{
Mozart's Sonata for Two Pianos K448 in D-Major 2nd Movement Improves Short-Term Memory and Concentration
}

\author{
Yenni Limyati*, Roro Wahyudianingsih**, Revy D Maharani ***, \\ Maria T Christabella***
}

* Skills Lab Department Faculty of Medicine Maranatha Christian University/ Medical Rehabilitation Unit Immanuel Hospital Bandung

** Pathology Anatomy Department Faculty of Medicine Maranatha Christian University*** Faculty of Medicine Maranatha Christian University

Jl. Prof. drg. Suria Sumantri MPH No.65 Bandung 40164 Jawa Barat Indonesia

\author{
Email:y_nni@yahoo.com
}

\begin{abstract}
Rhythm, melody, and high frequencies in Mozart's music are capable to stimulate creativity and motivation regions of the brain and activate brain's areas, especially the prefrontal area of the brain, which contributes to short-term memory. Listening to Mozart 's music can enhance concentration because it stimulates alpha brain waves which induce relaxation and peaceful mood. The objectives of this study were to determine the Mozart's effect towards short-term memory and concentration. This is a quasi-experimental study using preand post-test design, performed to 30 adult women aged between 19-24 years old. The measured data were memorized words from recall memory test and duration to finish traffic jam puzzle, before and after listening to Mozart Sonata K448 for Two Pianos in D-major $2^{\text {nd }}$ Movement. Data were analyzed using paired t-test with $\alpha=0.05$. The results showed that there is a significant difference of words remembered before and after listening to music $(35,43 \pm 6,70444$ vs $73 \pm 4,727 ; \quad p<0,01)$ and duration to finish traffic jam

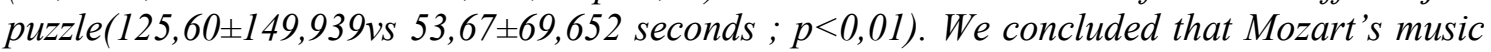
improves short-term memory and concentration.
\end{abstract}

Keywords: Mozart's sonata, short-term memory,concentration 


\title{
Mozart Sonata K448 For Two Pianos in D-Major 2nd Movement terhadap Memori JangkaPendek dan Konsentrasi
}

\author{
Yenni Limyati*, Roro Wahyudianingsih**, Revy D Maharani ***, \\ Maria T Christabella**** \\ *Bagian Keterampilan Klinik Fakultas Kedokteran Universitas Kristen \\ Maranatha/Instalasi Rehabilitasi Medik RS Immanuel Bandung \\ ** Bagian Patologi Anatomi Fakultas Kedokteran Universitas Kristen Maranatha, \\ ***Fakultas Kedokteran Universitas Kristen Maranatha \\ Jl. Prof.Drg. Surya Sumantri, MPH No 65 Bandung 40164 Indonesia \\ Email: y_nni@yahoo.com
}

\begin{abstract}
Abstrak
Melalui ritme, melodi, dan frekuensi-frekuensi tinggi, musik Mozart mampu merangsang daerah kreatif dan motivasi dalam otak dan mengaktivasi area otak, terutama area prefrontal otak yang berperan dalam memori jangka pendek. Efek mendengarkan musik sonata Mozart juga dapat meningkatkan konsentrasi karena merangsang pelepasan gelombang alfa yang menimbulkan keadaan relaks dan tenang. Tujuan penelitian ini adalah untuk mengetahui efek sonata Mozart terhadap memori jangka pendek dan konsentrasi. Desain penelitian ini bersifat kuasi-eksperimental menggunakan rancangan pre-dan post-test dilakukan terhadap 30 wanita dewasa berusia 19-24 tahun. Data yang diukur adalah rerata jumlah kata yang dapat diingat dari tes recall memory dan rerata waktu menyelesaikan traffic jam puzzle. Kedua tes dilakukan sebelum dan sesudah mendengarkan Mozart Sonata K448 for Two Pianos in D-major 2nd Movement. Data dianalisis menggunakan uji $\mathrm{t}$ berpasangan dengan $\alpha=0,05$. Hasil penelitian adalah rerata jumlah kata yang diingat sebelum- $35,43 \pm 6,704$ dan sesudah$44,73 \pm 4,727(p<0,01)$ dan rerata waktu menyelesaikan traffic jam puzzlesebelum125,60 $\pm 149,939$ detik dan sesudah mendengar Mozart Sonata K448 for Two Pianos in D-major 2ndMovement 53,67 $\pm 69,652$ detik $(p<0,01)$. Simpulan penelitian ini efek sonata Mozart dapat meningkatkan memori jangka pendek dan konsentrasi.
\end{abstract}

Kata kunci : konsentrasi, sonata Mozart, memori jangka pendek. 


\section{Pendahuluan}

Musik adalah bahasa yang mengandung unsur universal. ${ }^{1}$ Musik merupakan bagian dari seni yang tidak terpisahkan dari kehidupan manusia. Banyak aktivitas manusia diiringi oleh musik, seperti saat bersantai, berbelanja, mengemudi, bekerja, dan belajar. Cara belajar seseorang pun beragam antara lain visual (belajar mengandalkan penglihatan), audio (belajar mengandalkan pendengaran), read-write (belajar dengan cara membaca dan menulis), kinestetik (belajar mengandalkan pergerakan). ${ }^{2}$

Musik memiliki efek terhadap kerja sistem tubuh manusia. Saat mendengarkan musik terjadi pengaturan hormon-hormon stres, musik juga dapat memperkuat memori jangka pendek, serta memperlambat dan menyeimbangkan gelombang otak antara belahan otak kiri yang logis dengan belahan otak kanan yang intuitif. ${ }^{1}$ Salah satu contoh musik klasik yang dapat digunakan dalam proses belajar ialah musik klasik karya Mozart. Beberapa penelitian menunjukkan bahwa struktur dari musik Mozart sesuai dengan pola gelombang otak manusia. Salah satu efek musik klasik karya Mozart yang sedang diteliti dalam bidang kesehatan ialah Mozart Sonata K 448 for Two Pianosin D Major 2nd Movement.Andante atau lebih sering disebut sebagai 2 nd movement merupakan bagian yang sering digunakan karena memiliki pengulanganmelodi dan irama setiap dua puluh sampai tiga puluh detik yang selaras dengan struktur gelombang alfa otak manusia, sehingga ketikagelombang alfa aktif akan menciptakan suasana tenang, meningkatkan memori jangka pendek dan meningkatkan konsentrasi. ${ }^{3}$

Menurut Kamus Besar Bahasa Indonesia, konsentrasi adalah pemusatan perhatian atau pikiran pada suatu hal. ${ }^{4}$ Memori atau ingatan adalah penyimpanan informasi yang didapat untuk dapat diingat kembali kemudian. Penyimpanan informasi yang didapat dilakukan paling sedikit melalui dua cara yaitu memori jangka pendek dan memori jangka panjang. Memori jangka pendek berlangsung beberapa detik hingga jam sedangkan memori jangka panjang dipertahankan dalam harian hingga tahunan. ${ }^{5}$ Informasi yang baru diperoleh pada awalnya diendapkan di memori jangka pendek yang kapasitas penyimpanannya terbatas. Saat seseorang memasukkan sebuah informasi dan terus mengulangnya, maka informasi tersebut akan masuk ke dalam proses selanjutnya yaitu memori jangka panjang. Saat informasi itu diperlukan, seseorang dengan mudah mengingat kembali (recall), karena informasi yang telah disimpan tersebut kemudian dikembalikan dari memori jangka panjang ke memori jangka pendek. ${ }^{5,6}$

Tujuan penelitian ini adalah untuk mengetahui efek music Mozart Sonata K 448 for TwoPianos in D-Major $2^{\text {nd }}$ Movement terhadap memori jangka pendek dan konsentrasi. 


\section{Research Article}

\section{Metode}

Penelitian ini merupakan penelitian eksperimental-kuasi dengan rancangan pre-test dan post-test. Penelitian dilaksanakan di Laboratorium Komputer Graha Widya Maranatha (GWM) lantai 9 Universitas Kristen Maranatha.Subjek penelitian adalah 30 orang mahasiswi Fakultas Kedokteran Universitas Kristen Maranatha yang memenuhi kriteria inklusi yaitu usia 19-25 tahun, menyukai musik klasik, bersedia menjadi subjek penelitian secara sukarela dan menandatangani surat persetujuan penelitian dan tidak tergolong ke dalam kriteria eksklusi yaitu gangguan pendengaran, kondisi stress. Subjek penelitian melakukan 2 uji yaitu tes recall memory untuk menilai memori jangka pendek dan mengerjakan traffic jam puzzle untuk menilai konsentrasi. Kedua uji dilakukan sebelum dan sesudah mendengarkan Mozart Sonata K 448 for TwoPianos in D-Major $2^{\text {nd }}$ Movement dengan jeda waktu antara pre-test dan post-test selama 10 menit untuk istirahat. Alunan musik Mozart diperdengarkan melalu headphone selama 10 menit istirahat tersebut dan tetap diperdengarkan selama melakukan post-test.Tes recall memory (disediakan lembar soal berbeda untuk pre-test dan post-test) dilakukan dengan cara subjek penelitian diberi waktu 5 menit untuk mengingat kata-kata yang ada pada lembar soal kemudian diberi waktu 5 menit untuk menuliskan semua kata-kata yang dapat diingat. Mengerjakan traffic jam puzzle dengan cara menggeser semua mobil yang ada dengan cara dimajukan atau dimundurkan sehingga terdapat jalan agar mobil merah dapat keluar menuju pintu keluar, kemudian dicatat waktu yang dibutuhkan subjek penelitian untuk menyelesaikan puzzle tersebut.

Data yang terkumpul diolah melalui analisis statistik menggunakan perangkat SPSS 24.0. Dilakukan uji normalitas Shapiro-Wilk, bila data berdistribusi normal dilanjutkan dengan uji t berpasangan, bila data tidak berdistribusi normal dilanjutkan dengan uji Wilcoxon untuk menguji rerata dari tes recall memory dan traffic jam puzzle sebelum dan sesudah mendengarkan musik Mozart dengan batas kemaknaan $\alpha=5 \%$.

Penelitian ini telah mendapatkan persetujuan etik dari Komisi Etik Universitas Kristen Maranatha dengan surat keputusan komisi etik No. 062/KEP/V/2015danNo. 080/KEP/V/2015

\section{Hasil}

Hasil uji normalitas Shapiro-Wilk menunjukkan kedua data (pre- dan post-test) terdistribusi normal $(p \geq 0,05)$ sehingga dilanjutkan dengan analisis statistik parametrik uji $\mathrm{t}$ berpasangan.

Hasil rerata pada pengukuran pre-test dan post-test, selisih rerata serta hasil uji t berpasangan disajikan pada tabel 1 . 
Tabel 1 Rerata Hasil Uji Tes Recall Memory dan Traffic Jam Puzzle

\begin{tabular}{llll}
\hline \multirow{2}{*}{ Jenis Uji } & \multicolumn{2}{c}{ Rerata \pm SD } & Nilai $\mathrm{p}$ \\
\cline { 2 - 4 } & $\begin{array}{l}\text { Pre-test } \\
\mathrm{n}=30\end{array}$ & $\begin{array}{l}\text { Post-test } \\
\mathrm{n}=30\end{array}$ & $<0,01 * *$ \\
\hline Tes Recall (jumlah kata) & $35,43 \pm 6,704$ & $44,73 \pm 4,727$ & $<0,01 * *$ \\
Traffic Jam Puzzle (detik) & $125,60 \pm 149,939$ & $53,67 \pm 69,652$ & \\
\hline $\begin{array}{l}\text { Keterangan : } \\
\text { SD Standar Deviasi } \\
* * \text { sangat signifikan }\end{array}$ & & & \\
& & &
\end{tabular}

Berdasarkan tabel 1 terdapat peningkatan rerata jumlah kata yang dapat diingat saat melakukan tes recall memory setelah mendengarkan musik klasik Mozart Sonata K 448 for TwoPianos in D-Major $2^{\text {nd }}$ Movement menjadi 44,73 $\pm 4,727$ dibandingkan sebelum mendengarkan musik sonata Mozart 35,43 $\pm 6,704(\mathrm{p}<0,01)$. Pada tabel 2 terdapat selisih rerata jumlah kata yang dapat diingat setelah mendengarkan musik klasik sonata Mozart sebesar $9,300 \pm 4,743(p<0,01)$. Pada tabel 1 rerata waktu yang diperlukan subjek penelitian untuk menyelesaikan traffic jam puzzle sebelum mendengarkan musik klasik sonata Mozart adalah $125,60 \pm 149,939$ detik, sedangkan rerata waktu yang diperlukan subjek penelitian untuk menyelesaikan traffic jam puzzle setelah mendengarkan musik klasik sonata Mozart adalah $53,67 \pm 69,652$ detik.

Tabel 2 Selisih Rerata Menyelesaikan Uji Tes Recall Memory dan Traffic Jam Puzzle Sebelum dan Setelah Mendengarkan Musik Klasik Mozart Sonata K 448 forTwo Pianos in D-Major $2^{\text {nd }}$ Movement

\begin{tabular}{lcccc}
\hline \multicolumn{1}{c}{ Jenis Uji } & $\begin{array}{c}\text { Selisih } \\
\text { Rerata }\end{array}$ & SD & Uji t & Nilai p \\
\hline Tes Recall Memory (jumlah kata) & 9,300 & 4,743 & 10,740 & $<0,01^{* *}$ \\
Traffic Jam Puzzle (detik) & 71,933 & 106,998 & 3,682 & $<0,01^{* *}$ \\
\hline
\end{tabular}

Keterangan :

SD Standar Deviasi

** sangat signifikan

Pada tabel 2. terdapat percepatan rerata waktu menyelesaikan traffic jam puzzle setelah mendengarkan musik klasik sonata Mozart dengan selisih sebesar 71,933 $\pm 106,998$ detik. 


\section{Diskusi}

Mendengarkan musik melibatkan 2 sistem penghubung yaitu sistem penghubung eksternal dan internal. Keterlibatan sistem penghubung eksternal saat mendengarkan musik, diawali saat bunyi yang masuk melalui telinga kita ditangkap oleh koklea. Frekuensi suara rendah akan merangsang sel - sel di daerah apeks, sementara bunyi dengan frekuensi tinggi akan ditangkap di dasar koklea. Kemudian melalui jaras vestibulo koklearis, impuls tersebut akan menuju nukleus koklearis ventralis di daerah medulla oblongata, dilanjutkan ke kolikulus inferior di batang otak melalui jaras lemniskus lateralis. Dari kolikulus inferior impuls suara musik tadi diteruskan ke brakium kolikulus inferior, lalu ke korpus genikulatum medialis dan terakhir diterima di lobus temporalis superior. Mulai dari lobus itulah musik memengaruhi berbagai macam bagian di dalam otak kita, seperti amigdala, tegmentum, striatum, lobus temporalis superior, daerah prefrontal dan beberapa bagian lainnya, seperti girus Heschl yang berperan dalam pengenalan musik yang didengar. ${ }^{7,8}$ Penelitian mengenai keterlibatan sistem penghubung internal masih sedikit, namun melibatkan emosi, sosial dan self relevant processes. ${ }^{7}$

Penelitian ini menggunakan musik klasik Mozart berjudul Sonata K 448 for Two Pianos in D-Major $2^{\text {nd }}$ Movement yang memiliki pengulangan melodi danritme yang kuat, selaras dengan gelombang otak manusia sehingga dapat merangsang gelombang alfa dan menyebabkan seseorang dapat lebih berkonsentrasi. ${ }^{3}$ Didapatkan percepatan rerata waktu menyelesaikan traffic jam puzzle sebesar 71,933 $\pm 106,998$ detik dengan hasil yang sangatsignifikan $(\mathrm{p}<0,01)$ seperti tampak pada tabel 2. Hal ini menunjukkan terjadi peningkatan konsentrasi yang dinilai dari subjek penelitian menyelesaikan traffic jam puzzle semakin cepat setelah mendengarkan musik klasik Mozart Sonata K 448 for Two Pianos in D-Major $2^{\text {nd }}$ Movement. Gelombang alfa terbukti dapat dipakai sebagai alat terapi. Musik dengan gelombang alfa dapat diperoleh melalui musik bertempo lambat (60-80 ketuk per menit). Tempo ini mampu menggeser gelombang otak dari gelombang beta $(14-8 \mathrm{~Hz})$ menjadi gelombang alfa $(8-12 \mathrm{~Hz})$, sehingga didapatkan kondisi yang relaks, santai, tenang. Keadaan ini akan membantu otak untuk meningkatkan memori jangka pendek. Terjadi peningkatan rerata jumlah kata yang dapat diingat saat melakukan tes recall memory setelah mendengarkan musik klasik sonata Mozart, seperti tampak pada tabel 1. Musik klasik dapat menciptakan serta merangsang area asosiasi dan keadaan belajar yang optimal. Musik klasik juga dapat menurunkan gelombang otak dan menyeimbangkan aktivitas antara belahan otak kiri dengan belahan otak kanan. ${ }^{1}$ Gelombang alfa juga dapat membantu merangsang pelepasan suatu peptida, yaitu beta-endorfin dan serotonin endogen yang memiliki 


\section{Research Article}

efek menurunkan tonus simpatis dan meningkatkan tonus parasimpatis, sehingga menimbulkan rasa tenang dan peningkatan konsentrasi. ${ }^{9}$

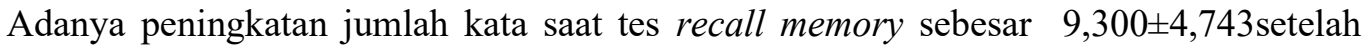
mendengarkan musik klasik sonata Mozart $(\mathrm{p}<0,01)$ pada tabel 2, sesuai dengan penelitian Edward Mjoen dari Winona State University pada tahun 2011, dengan subjek penelitian sebanyak 63 orang yang dibagi dalam 3 kelompok, lalu dibandingkan antara kelompok yang menghafal menggunakan musik klasik Mozart Sonata K 448 for Two Pianos in D Major 2ndMovement, tidak menggunakan musik, dan musik acak yang didengarkan langsung dari siaran radio. Setelah itu, setiap subjek diberi 10 kalimat yang masing-masing kelompok perlakuan kalimatnya berbeda-beda. Subjek diminta untuk mengingat kalimat-kalimat tersebut, lalu menuliskannya kembali semampunya. Hasil yang didapatkan adalah terdapat peningkatan yang signifikan dari skor hasil tes memori yang menggunakan musik Mozart Sonata K 448 for Two Pianos in DMajor 2nd Movement dibandingkan dengan yang menggunakan musik secara random ataupun yang tidak menggunakan musik. ${ }^{10}$

Tempo, melodi, dan frekuensi-frekuensi tinggi pada musik Mozart mampu merangsang daerah kreatif dan motivasi dalam otak. Tempo 60 ketuk per menit akan menyebabkan terjadinya keselarasan antara kerja otak dengan denyut jantung sehingga memberikan efek rileks dan meningkatkan konsentrasi. ${ }^{11}$ Sama halnya dengan penelitian yang dilakukan Yenni Limyati tahun 2012 menggunakan stimulasi ritmik atau tempo, diperoleh hasil latihan berjalan menggunakan stimulasi ritmik sistem pendengaran secara klinis lebih baik dibandingkan dengan latihan konvensional dalam memperbaiki pola berjalan pasien hemiparesis pasca-stroke. ${ }^{12}$

Musik memiliki getaran atau frekuensi, seperti pada piano. Kunci terendah piano adalah 27,5 Hz sedangkan kunci tertinggi piano adalah $4.186 \mathrm{~Hz}$. Saat seseorang mendengarkan musik, frekuensi musik dapat bertentangan atau beresonansi dengan frekuensi tubuh. Frekuensi tubuh berbeda-beda tergantung pada organ tubuh. Ketika terjadi kesamaan frekuensi, maka membran timpani akan bergetar dan merangsang parasimpatis. Kemudian, melalui nervus vagus, telinga dalam berhubungan dengan jantung dan paru-paru. Hal ini menyebabkan denyut jantung dan pernafasan lebih terkontrol. Seseorang akan merasa relaks tetapi waspada sehingga dapat belajar secara optimal. ${ }^{13}$ Dengan konsentrasi yang meningkat kita dapat belajar dan mengingat lebih baik. Memori yang tersimpan dalam otak secara fisiologis adalah dengan mengubah sensitivitas penjalaran sinaptik di antara neuron-neuron sebagai aktivitas neural sebelumnya. Suara musik yang masuk melalui telinga akan merangsang cortex cerebri lalu merangsang hipotalamus dan mengaktifkan sistem saraf simpatis sehingga 


\section{Research Article}

kesadaran dan kewaspadaan meningkat dan akhirnya mekanisme ini akan meningkatkan memori jangka pendek. ${ }^{14}$

\section{Simpulan}

Simpulan dari penelitian ini adalah musik sonata Mozart dapat meningkatkan memori jangka pendek dan konsentrasi.

\section{Daftar Pustaka}

1. Campbell D. The Mozart effect: tapping the power of music to heal the body, strengthen the mind, and unlock the creative spirit. New York: Haper Collins; 2009. 347 p.

2. Othman N, Amiruddin MH. Different perspectives of learning styles from VARK model. Procedia - Soc Behav Sci. 2010;7(2):652-60.

3. Habe K. Neuropsychology of music - a rapidly growing branch of psychology. Horizons Psychol. 2010;19(1):7998.

4. Nasional DP. Kamus Besar Bahasa Indonesia. [Internet]. Balai Pustaka; 2008. Available from: https://www.kbbi.web.id/konsentrasi

5. Sherwood L. Human physiology from cells to system. 8th ed. Belmont,USA: Yolanda Cossio; 2013.

6. Dharmawan T. Musik klasik dan daya ingat jangka pendek pada remaja. J Ilm Psikol Terap. 2015;3 (2):373.

7. Essi RS, Tammasse J, Muis A, Gunawan D. Pengaruh Terapi Musik Terhadap Peningkatan Skala Motorik Pada Penderita Stroke Iskemik Akut. Neurona. 2012;29(2).

8. Fritz US. Otak dan musik. Neurona. 2012;29(4):157-62.

9. Hurless N, Mekic A, Peña S, Humphries E, Gentry H, Nichols DF. Music genre preference and tempo alter alpha and beta waves in human non-musicians. Impuls Prem Undergrad Neurosci J. 2013;1-11.

10. Mjoen E. Music on mind : cognitive recall and reaction times. WSU Psychol Student Journal;2010.

11. Grimonia E. Dunia Musik. Nuansa Cendekia; 2014.

12. Limyati Y. Perbandingan latihan berjalan menggunakan stimulasi ritmik sistem pendengaran dengan latihan berjalan konvensional terhadap pola dan kemampuan berjalan pasien hemiparesis pasca stroke iskemik. J Indon Med Assoc. 2011;62(5):183-9.

13. Gunawan AW. Genius learning strategy. Jakarta: Gramedia Pustaka Utama.; 2007. 63, 254 p.

14. Guyton AC, Hall JE. Buku Ajar Fisiologi Kedokteran. 11th ed. Jakarta: EGC; 2014. 